\title{
Combating Corruption in Sport: Legal Aspect Lucha contra la corrupción en el deporte: aspecto legal
}

*Tetiana Kolomoiets, *Maxym Tkalych, **Petro M elnyk, *Bogdan Panchenko, ***YuliiaTolmachevska

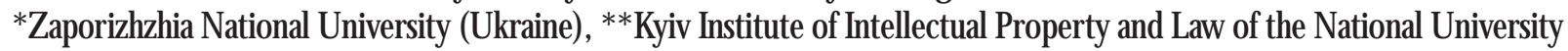
«0 desa Law Academy», ***N ational University «0 desa Law Academy» (Ukraine)

\begin{abstract}
G lobalization processes do not ignore any sphere of human life. They did not miss the field of sports. As a result, the problem of corruption, which used to be unequally prevalent in every national jurisdiction, is beginning to threaten the integrity of sport at the global level. Ther efore, legal science has a task to determine the legal al gor ithms for combating sports corruption both within the country and in the international arena. The study aims to establish legal mechanisms to combat corruption in sportsat both national and international levels. The object of research is public relations in the field of sports law. The subject of the study is public relations in the field of sports law, which have developed concerning methods and means of combating sports corruption. The research methods were philosophical, general scientific, and special scientific methods such as dialectical, system-structural, comparative-legal, and formal-legal methods. As a result of the work, a description of the state of research of the problem was given, the main approaches to defining the concept of sports corruption and matchfixing were analyzed, the legal framework (international and national) was characterized, specific examples of corruption offenses and their solution in sports were given.
\end{abstract}

Key words: sports, corruption, match-fixing, match manipulation, offense.

Resumen: Los procesos de globalización no ignoran ningún ámbito de la vidahumana. N o faltaron al campo de los deportes. Como resultado, el problema de la corrupción, que solía preval ecer de maneradesigual en todas las jurisdicciones nacionales, está comenzando a amenazar la integridad del deporte a nivel mundial. Por lo tanto, la ciencia jurídica tiene la tarea de determinar los al goritmos legal es para combatir la corrupción deportiva tanto en el país como en el ámbito internacional. El estudio tiene como objetivo establecer mecanismos legal es para combatir la corrupción en el deporte tanto a nivel nacional como internacional. El objeto de investigación son las relaciones públicas en el ámbito del derecho deportivo. El tema del estudio son las relaciones públicas en el campo del derecho deportivo, que se han desar rollado sobre métodos y medios para combatir la corrupción deportiva. Los métodos de investigación fueron filosóficos, científicos generales y métodos científicos especiales, como losmétodos dialéctico, estructural de sistema, legal comparativo y legal formal. Como resultado del trabajo se dio una descripción del estado de investigación del problema, se analizaron los principales enfoques para definir el concepto de corrupción deportivay partidos contractuales, se caracterizó el marco legal (internacional y nacional), ejemplos específicos de Se dieron a conocer los delitos de corrupción y su solución en el deporte.

Palabras clave: deportes, corrupción, amaño de partidos, manipulación de partidos, delito.

\section{Introduction}

The history of scandals sinvolving corruption in sports goes back to ancient times. There is evidence of the corruption in ancient Greece (Decker, 1995; Szymanski, 2009) and the Roman Empire (Swaddling, 1999). However, the problem of corruption offenses remains relevant today. Such information can be found in the media (Keegan, 2014), in the pages of reports of international organizations (KEA, 2012; UNODC \& IOC, 2016; Transparency International, 2016), in research (M aennig, 2005). In all probability, these annoying facts

Fecha recepción: 03-01-21. Fecha de aceptación: 10-02-21

Yuliia Tolmachevska

yuliiatolmachevska7@gmail.com have repeatedly caught our attention in everyday life.

M odern sport needs private legal mechanisms of regulation, because they provide the best way to protect the rights of individuals and legal entities - participants in relations in the field of sports (Tkalych, Davydova, \& Tolmachevska, 2020). Law, as a unique social phenomenon, arises with the emergence of the state, because an indispensable attribute of any legal norm is the possibility of using state coercion in case of noncompliance with its instructions (Tkalych, Safonchyk, \& Tolmachevska, 2020). As social relations in the field of sports became more complicated, there was an increasing need for their proper legal regulation (Kharytonov, Kharytonova, Kostruba, Tkalych, \& Tolmachevska, 2021).

So, the problem of sports corruption and match- 
fixing poses a great danger to the purity of the game and the integrity of sports competitions per se. This type of human activity has long been characterized by a set of virtues that required a great deal of effort, perseverance, adherence to high moral principles and ethical standards, not to mention strict sportsmanship and excellent physical shape. From the audience's point of view, theelement of unpredictability hasal ways added tension and increased passions when watching sports shows, which is the demand for their investment support. But at the same time, corruption risks are growing And since sport per se is the occupation of ambitious and competitive people, sometimes for them the goal justifies the means, and their own enrichment becomes a game without rules. Therefore, such manifestations of corrupt, dishonest behavior of individuals or entire organized groups call into question the very future of games, as well as their fundamental values and principles. Some experts even question whether this is «the greatest threat to 21st-century sport» (Carpenter, 2012, p. 13).

Since, as a type of human activity, sport is a social relationship, it is impossible to do without its legal regulation. It is also indisputable that the fight against corruption in the field of sport must be based on the principles of the rule of law, legality, fairness, and transparency of the methods used to combat it. According to the Law of Ukraine N 0. 743-VIII, they also include respect for human rights and fundamental freedoms, prevention, the involvement of public representatives in anti-corruption activities, and compensation for corruption damages (Part 1 of Article 3). All of the above applies to the new sports activities, including e-sports. Especially sincee-sportscompetitions are associated with attracting huge amounts of money.

Thus, legal science faces the task of providing an optimal mechanism of influence that will allow to effectively combat corruption in the field of sports. In this article, we will consider the main methods of such a struggle, and also we will outline the main vectors of their development.

\section{Material \& methods}

The methodological basis of the study are philosophical, general, and special scientific methods.

Thus, the system-structural method made it possible to formulate the main elements of legal regulation to combat corruption in sports in their combination and interaction.
Further, the application of the comparative-legal method was useful in analyzing the differences between national and international law in the fight against corruption, in particular in sports. The formal-legal method has proved its effectiveness in studying the content of legal norms in the aspect of combating sports corruption. The formal-legal method was used in the analysis of the current Ukrainian criminal and administrative legislation in the fight against sports corruption. In particular, this method was used to thoroughly investigate the composition of offenses under the Criminal Code of U kraine and the Code of Administrative $O$ ffenses of $U$ kraine.

Moreover, the method of analysis is reflected in the study of manifestations of sports corruption and legal regulation, which is responsible for combating such manifestations. The method of synthesis was used to find the best ways to develop anti-corruption legislation, to formulate conclusions on the subject of research.

W hat is more, the method of deduction has proved itself in thestudy of the specifics of anti-corruption norms as a reflection of the general principles of the legal systems of foreign countries.

Finally, the method of induction provided a generalization of the research topic based on scientific developments, in particular, empirical data on the preval ence of corruption in sports and law enforcement of anti-corruption legislation.

Concerning the elaboration of the problem in scientific sources and other literature, it should be noted at once that most of the research in this area of knowledge is primarily articles in the media based on the results of journalistic investigations. Therefore, it has become common practice to use them when quoting in scientific papers.

Researchers such as Carpenter (2012), M aennig (2002, 2005), M asters (2015), Serby (2015, 2017), $O$ liynyk and Bashta (2019), Zadoya (2015), Kryshevych and Savchenko (2017), Semenyuk and Nemich (2017) have paid attention to the issue of combating sports corruption in the legal field at various times. It should be borne in mind that the degree of development of the topic abroad far exceeds the national level of research, so profile and subject study and development of its own theoretical and legal framework for sports corruption and ways to combat it is a promising area of scientific legal research.

Thus, Carpenter (2012) in his work draws attention to the growing threat of match-fixing. The author suggests ways to ensure a balance of private and public 
interests to preserve the integrity of sport and prevent future misconduct.

In addition, Maennig (2002; 2005) in his articles investigated the prevalence of corruption in sports, gave his definition of the nature of the phenomenon, distinguishing doping and match-fixing

Furthermore, Masters (2015) describes the legal mechanisms for preventing sports corruption in foreign countries. The researcher depicts the relationship between the socio-economic aspects of the game and the means of legal response that must be used to ensure the integrity of the sport.

Besides, Serby $(2015 ; 2017)$ focuses on the details of international treaties, as well as the role of sports autonomy, the balance of public and private interests, and their role in combating sports corruption.

O liynyk and Bashta (2019) in his article considered the role of international experience in the fight against sports corruption. The conclusion is made about the important place of international agreements such as the $U N$ and Council of Europe conventionsfor international cooperation and improvement of national legislation in the studied aspect.

Such domestic researchers as Zadoya (2015), Kryshevych, and Savchenko (2017), Semenyuk and Nemich (2017) devoted their publications to the critique of the norms of criminal law regulation of combating corruption in sports. A common feature of their work is that the authors concluded that the design was imperfect, in particular, Art. 369-3 of the Criminal code of Ukraine (2001) in the aspect of its law enforcement.

It should also be noted that the issue of corruption in sports is covered by analytical collections, catalogs, and reports of various international organizations such as Transparency International (2016), United Nations $O$ ffice on Drugs \& Crime, International O lympic Committee (2016), European Council (KEA, 2012).

At the same time, cer tain aspects of corrupt relations in sports remain unexplored. In particular, in addition to match-fixing and machinations with doping tests of athletes, the problem of illegal betting in sports also needs meticulous attention. The point is that sports betting is not in itself illegal, but it does happen if the parties to the sport conspire for illicit gain. It seems that the mechanism for bringing to justice for fraudulent actions related to sports betting, as well as the mechanism for compensating for damages caused by such actions, need to be improved at both national and international levels.

\section{Results}

\section{The problem of definition}

It is worth noting that there is no consensus among researchers as to what exactly is meant by corruption in sports (Brooks, Aleem, \& Button, 2013; Kihl, Skinner, $\&$ Engelberg, 2017). Maennig (2005) notes that difficulties in determining to arise as soon as we begin to consider the type of competition in which the offense takes place, in which country, and even on which continent. He gave an interpretation of corruption in sports because of conflicts of interest, focusing on the aspect of bribery (M aennig, 2002). Thus, the scientist divided corruption into managerial and competition. For him, the essential signs of corruption are the presence of authority in the offender, the existence of a counterparty in the form of another person or institution, as well as violation of the public duty to comply with established rules and regulations in favor of their own interests or a third party. At the same time, such sports offenses as doping should be distinguished from corruption, as prohibited substances or methods can be used by one person. At the same time, bribery requires an active and a passive side (M æennig, 2005).

There have also been attempts to view sports corruption offenses through the prism of game theory (Bird \& Wagner, 1997). From this point of view, unscrupulous players choose fraud as the optimal strategy to achieve maximum results in a poorly regulated environment (M aennig, 2005).

According to Masters (2015), the basis for recognizing an act of corruption is a violation of the public interest. Thus, sports management, as well as the game itself should not contradict the principles of purity, honesty, and integrity, which will be expressed in compliance with public order. However, it does not mean that in competitions everything should always be fair. Thus, adding to this danger and unpredictability, unfair situations are also part of the game. For example, a team due to force majeure plays a weak lineup (most fell ill) and loses (CGTN, 2020); the 1966 FIFA World Cup final, where England won a dubious 4-2 victory over Germany (Reid \& Zisserman, 1996; Thomas, 2014); a goal scored by Diego Maradona in the quarterfinals of the 1986 W orld Cup (Dawnay, 2019); Marco Devic's uncounted goal against England at the 2012 European Championshipsin U kraine, etc. (Thomas, 2014). And let the goal-line technology (GLT) control system be designed to eliminate such annoyances, from 
a theoretical point of view and in the absence of facts that deny it, we assume that the arbitrators at the time of the above events acted on the principle bona fide, that is, of goodwill, honestly making decisions, even now it can be said unequivocally that it turned out to be unfair. The situation with unequal starting positions between rival teams is simpler (CGTN, 2020), as it arose due to circumstances that are weakly dependent on the will of the victims ( 12 player s of the main national football team of U kraine who fell ill with Covid-19).

Gorse and Chadwick (2011) proposed an approach to formulating the concept of sports corruption, which would mean any illegal activity involving material stakeholders, which is to distort the results of the competition. Criteria of morality and ethics are also a factor in characterizing actions in the field of sports as corrupt. M asters (2015) questionsthis approach because moral and ethical norms have their characteristics in different jurisdictions. It is also noted that the transfer of competition rights and related activities of sports governing bodies are not covered by the proposed definition. Thetypology of cor ruption in sport according to Gorse and Chadwick (2011) includes doping, matchfixing (gambling-related and non-gambling), and illegal insider trading. However, for the article, as the main manifestation of corruption in the field of sports, we propose to focus on match-fixing.

According to the definition in the Oxford English Dictionary, a match-fixing is an activity of dishonestly establishing the results of a competition before it takes place. According to Lamberti (2014), match-fixing can be with both fully and partially predetermined results.

It is fair to emphasize that the factor of unpredictability plays a crucial role in establishing the fact of illegal determination of the results of the competition in advance. It seems appropriate that the signs of a corruption offense arise when a person or group of persons acts in a manner expressly prohibited by law, or violates the rights and interests of others or the rules of public order, or contradicts the defining principles of the game. In this case, the parties to a corruption agreement may have both a personal interest and act in favor of third parties. It is also reasonable to assume that the principle of unpredictability is violated in the case when due to bribery the right to compete goes to a party who otherwise would not be able to get it in objective circumstances (lack of infrastructure, violations, or low living standards, freedom of speech, entrepreneurship, etc.). Confirmation of this point of view can be illustrated by the definition of manipulation of sports competitions, given in Part 4 of Art. 1 of the relevant Council of EuropeC onvention of 18 September 2014, according to which it is "an intentional arrangement, act or omission aimed at an improper alteration of the result or the course of a sport competition in order to remove all or part of the unpredictable nature of the aforementioned sport competition with aview to obtaining an undue advantage for oneself or for others».

Experience of anti-corruption legal regulation in the field of sports in the international arena

At the international level, several anti-corruption treaties can be applied to the field of sport. In this regard, it isnecessary to mention, first of all, the UN Convention against Corruption, which was adopted in N ew York on 0 ctober 31, 2003. It establishes the necessary international legal framework to combat corruption offenses, in particular, identifies vectors of theoretical and practical developments in combating corruption (Article 5), establishes the principles of functioning of anti-corruption structures in the public sector (Articles $6,7,12$ ), lists the acts to be criminalized (Chapter III), such as bribery of officials (Articles 15, 16), abuse influence and official position (Articles 18 and 19), bribery and theft of property in the private sector (Articles 21 and 22), etc. The UN Convention against Transnational 0 rganized Crime of N ovember 15, 2000, which details the procedural issues of criminal liability for corruption on an international scale, as well as cooperation between law enforcement agencies in this regard, is also in force.

We should also mention the participation of such an international organization as GRECO, which developed the Code of Conduct for Public Officials, which was approved by the Committee of Ministers of the Council of Europe (O liynyk, \& Bashta, 2019). The main point of its activity is to monitor compliance with international standards for integrity and transparency in sports, as well as to ensure control over the effectiveness of anticorruption, entrusted to GRECO under Art. 24 of the Criminal Convention of the Council of Europe on Combating Corruption of January 27, 1999. In turn, this agreement distinguishes between active and passive forms of bribery and introduces rules on good governance to be adopted by national jurisdictions.

The introduction mentioned the Council of Europe Convention against the $M$ anipulation of Sporting Events. It providesfor a system of interstatestandards to prevent the impact of match-fixing on the integrity of sport, 
regulates the role of bookmakers (Articles 10-12), and establishes the types of legal liability.

Although in most foreign countries approaches to the formulation of corruption in sport have several common basic features, each state tries to use theoretical and legal terminology that would most accurately link the legal definition with the cultural and legal reality of its environment. For example, the Spanish Supreme Court described the components of corruption as follows (Jabaloy, 2019). First, the offender must have the appropriate authority to commit the act of corruption. Secondly, the search for or receipt of tangible or intangible illicit benefits must take place outside its social moral, and ethical acceptance. The third feature should be the personal benefit or benefit of the third party. The Criminal Code of the Kingdom of Spain (1995) distinguishes between bribery against public and private individuals. It al so provides for passive and active forms of corruption. The objective side of the offense involves obtaining an improper benefit or advantage for a predetermined or altered test result (such as a doping test), match, or important sporting event.

Foreign countries choose the main way to combat corruption in sports isthe criminal ization of the relevant act and the creation of a legal framework that would ensure the fight against corruption:

a) in general;

b) in the field of sports, in particular.

For example, countries such as Australia, Bulgaria, France, New Zealand, and Spain have opted for the second option, and have introduced liability specifically for bribery in the field of sport separately from corruption liability in general (UNO DC \& IOC, 2016). The biggest difference in approaches between foreign

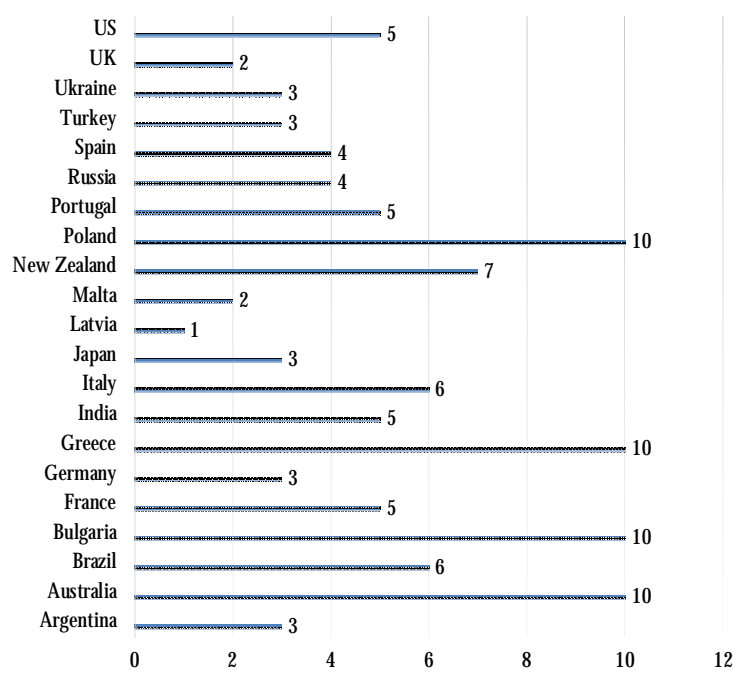

Figure 1. Maximum Imprisonment Sanctions (Non-aggravated Offences) For Sports Corruption, Years. Source: UN ODC \& IOC, 2016. countries can be found in the issue of sentencing, such as imprisonment for corruption offenses in sports. Thus, in the case of countries such as Argentina and France, we can see that the minimum prison sentences are one to two months, while in Brazil, El Salvador, and Italy they are up to two years. As for the maximum penalty for sports corruption, record terms of imprisonment (for a crime without aggravating circumstances) can be found in the legislation of Australia, Greece, and Poland (up to 10 years). At the same time, in Denmark, this period is up to 1 year (a list of maximum sanctions can be shown in Figure 1).

Aswe can see, despite the common goal of combating corruption offenses, adhering to the principles of law and justice, preserving the integrity of sports, approaches to penalizing corruption offenses are very different in different statejurisdictions. For example, ascan befound in M asters (2015), criminal law categories that define corruption in the field of sports as fraud are countries such as Austria, Denmark, Estonia, Germany, Hungary, Ireland, Latvia, Lithuania, TheN etherlands, and Slovenia. General anti-corruption legislation is preferred in Belgium, Greece, Luxembourg, Portugal, Romania, and Sweden. The Czech Republic, Slovakia, and Finland have a mixed system in this respect.

O ne of the topics related to the subject of research, which, however, is given little attention in the academic environment, is the procedural dimension of the legal fight against corruption in sports. In this regard, it should be noted that there are known cases when the participants in match-fixing avoided liability based on inadmissibility of the evidence used against them (Azkanar, 2017). In this case, we are talking about the decision of the Disciplinary Committee of the Football Federation of Turkey from 0 ctober 19, 2017, on the game between the teams of the second division $M$ anisaspor and Shanliurfaspor, which took place on M ay 14, 2017. Thus, the committee preferred national law to international practice. The contradiction here is that despite the evidence of Turkish criminal law in favor of the decision, it should not preclude the application of disciplinary sanctions. Therefore, the experience of dealing with such cases has been neglected, as FIFA, UEFA, and CAS have standards for resolving them. According to them, the admissibility of evidence in civil or criminal proceedings has a different effect on disciplinary proceedings. In particular, the requirements for the criteria of proof are both less stringent than «beyond reasonable doubt» and more stringent than the «probability ratio» (Court of Arbitration for Sport, 
2009). In this regard, the review body may find such evidence «sufficiently satisfactory» (Court of A rbitration for Sport, 2013). Besides, the case-law of the Swiss Federal Court, to which the CAS is governed, illustrates that in the case of significant public interest in resolving a dispute, illegally obtained evidence may be considered admissible under Swiss procedural law. Returning to the initial position of denial of justice from prosecution based on inadmissibility of evidence, wenotethat, caused by similar contradictory court decisions, the described situations have arisen in Turkish football before (Küçükkocaođlu, Sezgin Alp, \& Sultanoilmaz, 2018; Antonopoulos, 2019).

O ne of the types of the fight against sports corruption is financial monitoring. Let's illustrate this as follows. Prosecution of the FIFA gate case, a scandal involving the organization's long-standing activities that erupted in 2015, was made possible by effective control mechanisms by the US and Swiss law enforcement systems (Bayle \& Rayner, 2018). Despite the wave of criticism of the Swiss government, its joint actions with the FBI, such as raids on the hotel of FIFA top managers in Zurich in May and December 2015 (US Do), 2015; BBC Sport, 2015), fit into the logic of cooperation between the two countries, because the «dirty money» that FIFA officials received as a reward for their agreements somehow got into the US banking system (Bayle \& Rayner, 2018). In addition, a year earlier, Swiss banks (Swiss UBS, Credit Swiss) were forced to pay large fines in the United States for violating the socalled Foreign Account Tax Compliance Act (FATCA) (Bayle \& Rayner, 2018).Thus, asaresult of the application of reporting, control, and audit tools, decades of activity and agreements have been called into question, in particular on the selection of host countries for the 2018 FIFA World Cup in the Russian Federation and 2022 in $Q$ atar, which eventually led to the resignation of such football management greats like Michel Platini (then UEFA chairman) and Sepp Blatter (FIFA president) (Gibson, 2015). It is al so worth recalling that corruption allegations were leveled at FIFA and before the events depicted (Rumsby, 2014; Emmen, 2014).

\section{Features of national legislation to combat corruption in sports}

Similar to the developments of foreign jurisdictions, regulations in the field of combating sports corruption in U kraine can be divided into acts of public law of general and special regulation. The first includes the provisions of the Criminal Code of U kraine (2001), the
Code of Administrative $O$ ffenses of $U$ kraine (1984), and the Law No. 1700-VII of O ctober, 14, 2014 «0 n Prevention of Corruption». Acts of special regulation are the Law No. 743-VIII of November 3, 2015 «0 n prevention of the impact of corruption offenses on the results of official sports competitions», under Art. 17 and following Section $V$ of which amendments were made to the Criminal Code of U kraine and the Code of Administrative $O$ ffenses of $U$ kraine (Articles 369-3 and 172-9-1).

The following articles of the Criminal Code of Ukraine may be applied from the perspective of general criminal law provisions in order to tackle corruption in sports: 190 (fraud); 354 (illegal benefit reception by an employee of a state enterprise, institution or organization); 364-1 (abuse of official authority by an officer of a legal entity of private law, irrespective of organizational-legal form); 368 et seq. (bribe-taking); 369 et seq. (bribe-giving); 369-2 (abuse of influence) (UNODC \& IOC, 2016).

Penalties for corruption in sports can be divided into betting-related and non-betting-related match-fixing.

Following the rules of Art. 369-3 of the Criminal code of $U$ kraine, for distortion of results in the field of sportscriminal liability, is provided. The article isanorm of criminal law regulation, which covers a set of actions, i.e., provides for criminal liability for several corpus delicti. First, according to Part 1, Article 2. 369-3 of the Criminal Code of U kraine, provides for a sanction for influencing the results of official sportscompetitions. Law N 0. 743-VIII uses the term "official sports competition», to which the norms of the Criminal Code apply. Therefore, according to para. 6 art. 1 of the Law of $U$ kraine « $0 \mathrm{n}$ Prevention of the Impact of Corruption 0 ffenses on the Results of 0 fficial Sports Competitions», such measures are recognized (sports competitions), which are provided by the U nified calendar plan of physical culture and sports activities of Ukraine. This document aims to determine the issues of organizational and financial nature concerning the preparation and conduct of sports competitions for a specified period (calendar year). The plans are published annually by the M inistry of Youth and Sports, which is responsible for issuing an order adopting a U nified Calendar Plan. As for the subject composition, it is stated that the competition is held by the organizer with the appropriate authority. The purpose of such competitions is to determine the winners under the rules of the respective recognized sport in U kraine. It should also be borne in mind that the competition regulations apply. 
So, as we see, events that are not covered by the concept of official sports competitions are not included in the scope of Art. 369-3 of the Criminal Code of U kraine.

Continuing the description of the corpus delicti under Part 1 and 2 of Art. 369-3 of the Criminal Code of U kraine, which are correlated as basic and qualified, it should be noted that one of the conditions of qualification from the point of view of the objective side of the crime is to obtain improper benefit as a result of the act. It is envisaged that it may apply to both the offender and third parties. Committing a crime under Part 1 of Art. 369-3 of the Criminal Code of Ukraine in relation to official sports competitions with the participation of minors or if such a criminal act was committed repeatedly, liability for it is provided in accordance with Part 2 of Art. 369-3 of the Criminal Code of U kraine, which constitutes a restriction or imprisonment for a term of two to five years. In turn, the sanctions of Part 1 of Art. 369-3 of the Criminal Code of U kraine provides for a minimum penalty in the form of a fine, which can range from two hundred to one thousand non-taxable minimum incomes. Restriction of liberty under Part 1 of Art. 369-3 of the Criminal Code of U kraine is from one to three years, and the maximum penalty is imprisonment for up to three years.

It should be added that for the qualification of the act under Part 1, 2 of Art. 369-3 of the Criminal Code of Ukraine, a necessary element of the crime will be the presence of a person of direct intent.

If you literally interpret the note to Art. 369-3 of the Criminal Code, at first glance it may seem that the subject of the crime under Part 1, 2 of Art. 369-3 of the Criminal Code of U kraine is special. However, among the ways of influencing official sports competitions, including bribery, coercion, incitement and conspiracy, only in the first case will there be a special entity, which may be athletes, sports support staff or sports officials. And this is only in the case of a passive form of bribery. In all other scenarios, including the active form of bribery, there will be a common subject of the crime.

Illegal placement of a bet is an independent corpus delicti under Part 3 of Art. 369-3 of the Criminal Code of $U$ kraine. In order to qualify an act under this criminal law, it is necessary to take into account that its objective side requires a mandatory element in the form of obtaining an illegal benefit. It must be more than twenty subsistence minimums. It is assumed that its acquisition may take place both concerning the offender and in favor of third parties. Thus, this is an example of a crime with a material component. It is made up of athletes, sports support staff or crime sports officials whose teams are taking part in the competition. Thus, the subject of the crime is special. The prohibition established by Part 4 Art. 8 of the Law N $0.743-\mathrm{VIII}$, is violated with direct intent. Sanction of Part 3 of Art. 369-3 of the Criminal Code of Ukraine provides for punishment in the form of a fine, restriction or imprisonment for a term of two to five years.

We remember that in the case of a criminal act, which will be covered by all parts of Art. 369-3 of the Criminal Code of U kraine, this will be an example of an ideal set.

It is also worth mentioning the norm of Art. 172-91 of the Code of Administrative $O$ ffenses of $U$ kraine on the prohibition of placing bets on sports with manipulation of official sports competitions. In this context, the difference between an administrative and a criminal penalty lies in the amount of the undue advantage obtained. According to Art. 172-9-1 of the Code of Administrative O ffenses of U kraine, it does not exceed twenty subsistence minimums for ablebodied persons. Sanctions of the norm on administrative offense include confiscation of illegally obtained profits, and in case of committing the offense again within a year, the person is deprived of the right to hold certain positions and engage in certain activities for a period of 1 year.

Finally, it isworth focusing on the problematic issues. Obviously, the main problem of criminal liability for sports corruption is the application of Art. 369-3 of the Criminal Code of Ukraine. Thus, at the time of writing, there is no conviction under this article. This calls into question its effectiveness. A similar situation occurs concerning administrative liability under Art. 172-9-1 of the Code of Administrative O ffenses of U kraine. $M$ oreover, the norms of these articles do not even appear in the accusations, but are only mentioned in the motivating parts as a note that it is a corruption offense under current law. It should be added that Art. 369-3 of the Criminal Code of $U$ kraine contains several components of the crime, in connection with which it is advisable to consider its renaming with the simultaneous allocation of Part 3 in a separate article (Zadoya, 2015).

It is also clear that in the aspect of combating sports corruption, larger investigations are needed, in particular, with the involvement of international experts and in close cooperation with foreign law enforcement agencies, for example, in thefield of financial monitoring. An example is the above-mentioned joint operations of 
the Swiss police and the US FBI. These measures are designed to create an evidence base for further prosecution of suspects in corruption in sports. However, in this aspect, it is also fair to note that the basis for such interaction lies not only in the legal but also in the political and economic spheres, so it requires both political will and budgetary resources.

At the same time, national governments themselves often block measures to combat corruption in sports. The corruption component is especially significant in developing countries, where the ambitions of the rulers are strong, and the pressure of public opinion, the mechanisms of control over power and expenditure of funds are weak. This is fully reflected in the words of former FIFA General Secretary Jerome Valcke «The less democracy a country has, the better for preparing for theWorld Cup,» he said in 2013, when preparing for the 2014 World Cup in Brazil (https:// www. reuters.com/ article/ us-soccer-fifaidU SBRE93N 18F20130424).

Thus, competent legislation alone is not enough to overcome corruption in sports: economic, political, ideological and other factors are of no less importance, as was shown above.

\section{Discussion}

Due to the fact that sport is relatively autonomous, the set of means to combat corruption in sport includes both legal and soft law means. And if the internal regulatory mechanisms in sports are not enough to detect corruption and bring the perpetrators to justice, then the application of legal norms providing legal liability for illegal actions becomes inevitable.

of course, due to the diversity of relations in the field of sports, a rather large list of acts could beincluded in the category of sports corruption. However, the definition of Gorse and Chadwick (2011) is the most concise. However, it includes its main manifestations. According to them corruption in sports includes doping, match-fixing (gambling-related and non-gambling), and illegal insider trading.

At the same time, match-fixing is the basis of corruption in sports, respectively, thisiswhat the authors of this article focused on.

In particular, the authors of the article came to the conclusion that there is currently no unified approach to the legal regulation of relations related to the application of legal liability for match-fixing. First of all, each country has the opportunity to apply general legislation to regulate these relations. However, it is not always able to adequately solve all the problems related to the match-fixing in sports. Accordingly, some countries are following the path of adopting special legislation to regulate these relations. In particular, in U kraine there is a special law that provides for the application of criminal and administrative liability in sportsfor the match-fixing. In pursuance of the provisions of this law, appropriate amendments were al so made to the Criminal Code of $U$ kraine and the Code of Administrative $O$ ffenses of U kraine.

0 ther countries around the world al so use both general and specific legislation to combat corruption in sport. Some of them, like Ukraine, have a mixed system.

It should be noted that national law can be applied for corruption offenses in sport only if the sport is officially recognized by the state. If there is no official recognition, it is impossible to prosecute a person for corruption under national law. However, this possibility remains if the rules of jurisdiction allow the application of transnational law (for example, EU law). In addition, there is a corresponding possibility if the responsibility for an act of corruption is provided by local documents of the governing bodies in the relevant sport, within their competence and in accordance with the principle of autonomy of sport.

Of course, the introduction of relevant norms in the criminal and administrative legislation of U kraine is a positive factor, while the acts of national sports federations and other governing bodies in the field of sportsshould al so be supplemented to combat corruption in rapidly developing sports.

Thus, with the development of sports there are new types of corruption offenses in the field of sports, one of the main of which is the match-fixing. At the same time, both national and transnational legal systems and the «sports law and order» are gradually improving the legal and quasi-legal mechanisms for combating such acts.

\section{Conclusions}

Summarizing the above information on the topic, we can draw the following conclusions.

First, the terminological dimension of the subject of research remains debatable. However, when specifying criteria, for example, if the task isto provide a definition of manipulation of the results of sporting events, or match-fixing, it can be argued that this implies a breach of public interest through unfair conduct aimed at 
distorting the unpredictable course of competition.

Secondly, the international legal framework for combating sports corruption consists mainly of relevant UN Conventions, in particular, against the corruption of 310 ctober 2003, the transnational crime of 15 November 2000. In this àspect, regional regulation, represented by the Council of Europe treaties, plays an important role, for example, the Criminal Convention for the Suppression of Corruption of 27 January 1999 and the Convention against the M anipulation of Sport of 18 September 2014.

Third, it is important to pay attention to the differentiation of the penalties that await violators of the ban on manipulating the results of sports competitions, related and unrelated to sports betting Procedural peculiarities regarding the use of evidence in contractual proceedings must also be taken into account. In particular, the experience of Turkey and the disciplinary institutions of international sports management organizations such as FIFA, UEFA, as well as the practice of CAS can be useful.

Fourth, concerning Ukrainian legislation, it should be noted that typologically it is divided into acts of general and special anti-corruption legal regulation. The first includes the Code of Administrative O ffenses of U kraine, the Criminal Code of U kraine, and the Law of Ukraine «O $\mathrm{n}$ Prevention of Corruption» of 0 ctober 14, 2014. The second should include the Law «0 n Prevention of Corruption O ffenses on the Results of O fficial Sports Competitions» of N ovember 3, 2015, and the provisions of Art. 172-9-1 of the Code of Administrative O ffenses of U kraine and Art. 369-3 of the Criminal Code of U kraine, which were introduced following this Law.

At the same time, the lack of case law on contractual rules is a matter of concern. Approaches to addressing this issue are to bring national legislation in line with international standards, in particular, guided by the principles of legal certainty and legal economy, as well as closer cooperation with foreign countries and the use of their experience in combating corruption in sport.

\section{References}

Azkanar, 0. (2017, N ovember 27). Illegally obtained evidence in match-fixing cases. The Turkish perspective. Retrieved from: https:/ / bit.ly/ 3l1Frkf.

Bayle, E., \& Rayner, H. (2018). Sociology of ascandal: theemergence of'FIFAgate'. Soccer \& Sodety, 19 (4), 593-611, D O I: 10.1080/
14660970.2016 .1228591$.

Bird, E., \& Wagner, G. (1997). Sport as a common property resource. Journal of Conflict Resolution, 41, 749-766. Retrieved from: https: / / econpapers. repec. org/ article/ saejocore/ v_3a41_3ay_3a1997_3ai_3a6_3ap_3a749-766.htm Brooks, G. Áleem, A. \& Button, M. (2013). Defining Fraud and Corruption in Sport. In: Fraud, Corruption and Sport. London: Palgrave Macmillan. Retrieved from: https:/ / bit.ly/ 37cuFTA.

Carpenter, K. (2012). M ach-Fixing - theBiggestThreat to Sport in the 21st Century? International Sports Law Review 2(1), 1324. Retrieved from: https:/ / bit.ly/ 2V1cU kq.

Court ofArbitration for Sport. (2009). IAAF v. RFEA \& Josephine O nyia: 2009/ A/ 1805; 2009/ A/ 1847. Retrieved from: https:/ / bit.ly/ 3q1U 09w.

Court of Arbitration for Sport. (2013). Public Joint-Stock Company «Football Club M etalist» v. Union desAssociations Européennes de Football (UEFA) \& PAOK FC: 2013/ A/ 3297. Retrieved from: https:/ / bit.ly/ 3nQ HrO b.

COVID-19 wreaks havoc on France, U kraine and Portugal teams ahead of international fixtures. (2020, 0 ctober 7). CGTN. Retrieved from: https: / bit.ly/ 35Zg8eq.

Dawnay, 0. (2019, June6). Argentinalegend Diego Maradonasays 'H and of God' goal against England was' symbolic revenge' for the FaklandsWar. Talksport. Retrieved from: https:/ / bit.ly/ 300nZ1D.

Decker, W. (1995). Sport in der griechischen Antike.Vom minoischen Wettkampf bis zu den Olympischen Spielen. [Sport in Greek antiquity. From the Minoan tournament to the Olympic Games]. München: Beck.

Emmen, M. (2014, N ovember 21). FIFA's faustian bargain: Corruption for the cup. Retrieved from: https:/ / bit.ly/ 3pYvlV4.

European Football Championship. (2012). England 1: 0 U kraine. Group stage. Retrievedfrom: https: / soccer365.ru/ games/ 10071101/.

Fifacrisis: US charges 16 moreofficialsafter earlier Zurich arrests. (2015, December 4). BBC Sport. Retrieved from: https:/ / www. bbc. com/ sport/ football/ 34991874.

Gibson, 0. (2015, December 21). Sepp Blatter and M ichel Platini banned from football for eight years by FIFA. The Guardian. Retrieved from: https: / bit.ly/ 2] acXb3.

Gorse, S., \& Chadwick, S. (2011).Theprevalence of corruption in international sport: A statistical analysis. Coventry: Centre for the International Business of Sport. Retrieved from: https:/ / bit.ly/ 379vZXd.

Jabaloy, J. (2019, December 4). Spain - Global bribery offenses guide. Retrieved from: https:/ / bit. ly/ 3nT tqPF.

KEA. (2012). Match-fixing in sport: a mapping of criminal law provisions in EU 27. Study for the European Commission. Retrieved from: https: / op.europa. eu/ s/ omHK.

Keegan, M. (2014, September 17). Match-fixing: Council of Europe set to introducean anti-corruption treaty. BBC. Retrieved from: http:/ / www. bbc. co. uk/ sport/ 0/ football/ 29235967. 
Kharytonov, E., Kharytonova, O., Kostruba, A., Tkalych, M., \& Tolmachevska,Y. (2021). To thePeculiarities of Legal and N onLegal Regulation of Social RelationsintheField of Sport. Retos 41, 131-137.

Kihl, L.A., Skinner, J., \& Engelberg,T. (2017). Corruption in sport: understanding the complexity of corruption, European Sport Management Quarterly, 17 (1), 1-5. DOI: 10.1080/ 16184742.2016.1257553.

Krysheych O.V., \& Savchenko, A.V. (2017). Illegal influence on the results of official sports competitions: problematic issues of criminal liability. Retrieved from: https:/ / bit.ly/ 36VI7wC.

Küçükkocaoðlu, G., Sezgin Alp, Ö., \& Sultanoðlu, B. (2018). Match-fixing in Turkish Football Super League: Fenerbahçe Case. Journal of Business Research - Turk, 10 (4), 646-660. DO I: 10.20491/ isarder.2018.541.

Lamberti,A. (2014). When thebeautiful gameturns ugly: A study of fan experiences of perceived match-fixing in soccer. Brock University: StCatherines

Maennig,W. (2002). O n theEconomicsof D opingand Corruption in International Sports Journal of SportsEconomics, 4, 61-89.

M aennig,W. (2005). Corruption in International Sportsand Sport Management: Forms, Tendencies, Extent and Circumstances. European Sport Management Quarterly, 5(2), 187-225. DO I: 10.1080/ 16184740500188821.

Masters, A. (2015). Corruption in sport: From the playing field to thefield of Policy. Policy and Society, 34(2), 111-123. Retrieved from: https:/ / bit.ly/ 3m56DQ z.

Match-fixing Definition of mach-fixing in 0 xford Dictionary. Retrieved from: https:/ / bit.ly/ 3kXCjG4.

Oliynyk, M.V., \& Bashta, I.I. (2019). International experience in combating corruption in sports. Current issues of domestic jurisprudence, 2, 171-175. Retrieved from: https:/ / bit.ly/ 393THqb.

Reid, I., \& Zisserman, A. (1996). Goal-directedVideo M etrology. In R. Cipolla, B. Buxton (Eds.), Proceedings of the 4th European Conference on ComputerVision, II, 647-658. N ewYork: Springer. Retrieved from: https:/ / bit.ly/ 33hDFFB.

Rumsby, B. (2014, September 18). Football Association dragged into FIFA controversy over $£ 1$ million worth of watches handed toWorld Cup nations. TheTelegraph. Retrieved from: http:/ / www.telegraph.co.uk/ sport/ football/ world-cup/ 11106.

Semenyuk, 0., \& Nemich, F. (2017). Unlawful influence on the results of official sportscompetitionsby bribery. Entrepreneurship, economy and law, 5, 214-217. Retrieved from: https:/ / bit.ly/ 3flkRu8.

Serby, T. (2015). The Council of Europe Convention on Manipulation of Sports Competitions: the best bet for the global fight against match-fixing? International SportsLawJournal, 15, 83-100. Retrieved from: https: / / bit.ly/ 2V5LZnf.

Serby, T. (2017). Sports Corruption: Sporting Autonomy, Lex Sportiva and the Rule of Law. Entertainment and Sports Law Journal, 15(2), 1-9. Retrieved from: https: / / bit. ly/ 3mhes5T. Swaddling, J. (1999). The Ancient Olympic Games. Austin, TX:
University ofTexas Press.

Swiss. (2007). Civil Procedure Code. Retrieved from: https:/ / bit.ly/ 2UW ge00.

Szymanski, S. (2009). Playbooksand Checkbooks:An Introduction to the Economicsof M odern Sports. Princeton, NJ: Princeton U niversity Press.

The Kingdom of Spain. (1995). Criminal Code. Retrieved from: https:/ / www.legisationline.org/ download/ id/ 6443/ file/ Spain_CC_am2013_en.pdf.

The United Stätes Department of Justice (USD o)). (2015, May 27). Nine FIFA O fficials and Five Corporate Executives Indicted for Racketeering Conspiracy and Corruption. Retrieved from: https: / bit.ly/ 3m5EuZp.

Thomas, K. (2014, June 5). Keeping an eye on the ball. SPIE Newsroom. DOI: 10.1117/ 2.2201406.01.

Tkalych, M., Daydova, I., \& Tolmachevska, Y. (2020). Current State and Prospects of Development of the Sports System of U kraine: Legal Aspects. Retos 38, 385-389. Retrieved from https:/ / recyt. fecyt.es/ index. php/ retos/ article/ view/ 76997.

Tkalych, M., Safonchyk, 0., \& Tolmachevska,Y. (2020). Private Law and human rights: New realities DIXI, 32, 1-12. DO I: https:/ / doi.org/ 10.16925/ 2357-5891.2020.02.04

Transparency International. (2016). Global Corruption Report: Sport. NewYork: Routledge.

Ukraine. (1984). Code of Ukraine on Administrative O ffenses Retrieved from: https:/ / bit.ly/ 3nRI7E0.

U kraine. (2001). Criminal code of Ukraine. Retrieved from: https:/ / bit.ly/ 364elTG.

U kraine. (2014). On theprevention of corruption. Retrieved from: https:/ / bit.ly/ 371GBHw.

U kraine. (2015). On prevention of influence of corruption offenses on results of official sports competitions. Retrieved from: https:/ / bit.ly/ 3ftxZgl.

U nited Nations 0 fficeon Drugs\& Crime, \& International O lympic Committee (UNODC \& IOC). (2016). Study on Criminal Law Provisions for the Prosecution of Competition Manipulation. Retrieved from: https:/ / bit.ly/ 306ZPmb.

United Nations. (1999). Anti-Corruption Criminal Convention No. ETS173. Retrieved from: https:/ / bit.ly/ 3l1GkJB.

U nited Nations. (2000). Convention against Transnational O rganized Crime Retrieved from: https:/ / bit.ly/ 33wBtuf.

U nitedN ations (2003). Convention againstCorruption. Retrieved from: https:/ / bit.ly/ 3fuBN OP.

United Nations. (2014). Convention against the M anipulation of Sporting Events Council of Europe. Retrieved from: https:/ / bit.ly/ 33f3l5A.

Yilmaz, S., Manoli,A.E., \&Antonopoulos, G.A. (2019).Ananđomy ofTurkish football match-fixing Trends in Organized Crime, 22, 375-393. Retrieved from: https:/ / bit. ly/ 2KHK5rn.

Zadoya, K.P. (2015). Scientific and practical commentary toArticle 369-3 of the Criminal Code of U kraine «lllegal influence on the results of official sportscompetitionss. Law and civil society, 2(11), 146-157. Retrieved from: https:/ / bit.ly/ 37æeqX9. 